\title{
The resentment of electors from the Brazilian city of Natal in the 2018 presidential election
}

\author{
O ressentimento do eleitor natalense \\ nas eleições presidenciais de 2018
}

Lindijane Bento Almeida [I] Terezinha Albuquerque Barros [II] Jaylan Ferreira Macedo [III]

\begin{abstract}
Political resentment has driven the rise of leaders and movements with extreme right profiles in recent years. In Brazil, this scenario gains other proportions after the presidential advantages of 2018. Therefore, the present work aims to understand the profile of voters who are resentful of Brazilian politics in the city of Natal-RN. The article analyzes the results of the last electoral election, relating to some aspects of social reality, characterizing the vote in the light of the theory of political resentment. We opted for the use of map resources for a spatial immersion of this phenomenon in the city's neighborhoods, which would consume a reading of the general characteristics of the electorate, indicating that resentment is not located only in the excluded places of the city.
\end{abstract}

Keywords: democracy; political resentment; presidential elections; polarization; Natal, RN.

\section{Resumo}

0 ressentimento político impulsionou, nos últimos anos, a ascensão de lideranças e de movimentos com perfis de extrema-direita. No Brasil, esse cenário ganha outras proporções depois das eleições presidenciais de 2018. Diante disso, o presente trabalho tem como objetivo compreender o perfil do eleitor ressentido com a política brasileira na cidade do Natal/RN. Este artigo analisa os resultados do último pleito eleitoral, relacionando-os com alguns aspectos da realidade social, visando a compreender o voto à luz da teoria do ressentimento político. Optamos pelo uso do recurso de mapas para uma imersão espacial nesse fenômeno nos bairros, o que permitiu uma leitura das características gerais do eleitorado, indicando que 0 ressentimento não se localiza apenas nos lugares excluídos da cidade.

Palavras-chave: democracia; ressentimento político; eleições presidenciais; polarização; Natal/RN. 


\section{Introduction}

The last few years have been marked by the rise of political leaders and social movements with an extreme right-wing political profile, as evidenced by the increase in the number of votes collected by parties with this same ideological orientation in several continents, such as in Europe, in North America and, more recently, in South America; as Brazil experienced in the last presidential elections held in 2018. New movements with a xenophobic, anti-establishment, and supremacist character take shape in countries like Germany, France, United States, and Hungary. Political populism reignites, in figures like Viktor Orbán (Hungary), Donald Trump (United States), Marine Le Pen (France), and Jair Bolsonaro (Brazil) become symbols of this group of resentful and disaffected people who see the future hopelessly of the country and democracy itself.

In Brazil, more specifically, movements with a claim to guarantee social rights give rise to demonstrations against corruption, making the great electoral agenda of 2018 enshrined, antipetismo, ${ }^{1}$ which becomes more intense after the impeachment of the then president, Dilma Rousseff, of the Workers' Party (PT), which breaks with the approval trajectory of previous years and initiates the high levels of popular disapproval in the period immediately after his reelection, in 2014. As well as advances in the anti-corrup operation, Lava-Jato ${ }^{2}$ which weakened several political parties, mainly the PT, allowing the rise of candidate Jair Bolsonaro (PSL). ${ }^{3}$
The "myth", as he is called by his most loyal supporters, introduces into the country's politics a public discourse totally different from what was seen in the last presidential elections. With demonstrations pro-militarism, pro-armament, attack on minorities, antiestablishment, besides being sympathetic to morally Christian values (in favor of the family, against abortion, against the agenda of the LGBTQI + population) and defender of an anti-corruption agenda, even though there are in his family and partisan nucleus people involved in cases of distortion with public money, Jair Bolsonaro becomes a protagonist, especially when he offers easy solutions to complex problems in Brazilian society.

To better understand this scenario, we seek to answer the reasons that led this candidate profile, with public speeches of glorification to authoritarian regimes, to rise as representative leadership, grounded with popular support, in a democracy that seemed to move more and more towards its consolidation, as in the Brazilian case. This situation bings to the fore an old debate in political science which claims that just free and fair elections are not enough elements to frame regimes as democratic or undemocratic, contrary to Schumpeter (1942), and Przeworski (1999), whose classic procedural views of democracy refer to a competitive election with equal conditions for victory. Przeworski (1999) still believes in the rationality of voters, when they choose their representatives based on a socially beneficial project. Not disregarding the elections as an essential element, but pointing it out as not enough, there is a series of authors (Dahl, 1996; Zakaria, 1997; Mainwaring, Brinks, and 
Pérez-Linã, 2001; Castells, 2018) that broadens the vision of democracy reiterating that the existence of a minimum category of social, political and civil rights is fundamental to classify a democratic regime.

Besides, disagreeing with Przeworski (1999), not only resentment can make people poor judges of their choices, but also leaders who are elected by popular vote will not always base their actions on the forms and rules of democracy that made them elected; since speeches that publicly weaken the constitutional and institutional norms of their countries have been part of these governments, so their leaders gain more power of influence and political representation.

Mounk (2018) also analyzes that the profile of these leaders has similar characteristics: they place themselves as sellers of easy solutions to problems and present themselves as defenders of a "cleansing" in politics. With a populist face, they convince those who don't want to admit that the real world can be complicated and that, dazzling themselves with illusions, they look for someone to blame for the supposed failure to solve these problems.

This new populism that emerges in the $21^{\text {st }}$ century takes on a new face of what has been seen in previous decades in continents such as Latin America: the emergence of leaders who, despite not using their sympathy, move masses in defense of anti-democratic measures. What strengthened the link with a population resentful of the performance of its representatives. These new leaders start to consider themselves as the faithful representatives of a heterosexual, white, Christian and conservative "majority". Thus, political pluralism is, in this new scenario, to be opposed, and the liberal pillars of guarantee of rights are at a secondary level in illiberal democracy, as denominated Zakaria (1997) and Mounk (2018).

Considering this context, the present work aims to understand the profile of the voter resentful of Brazilian politics, highlighting that, when it comes to Brazil and its territorial dimensions, the analysis proposed here becomes complex. In order to explore this political phenomenon, we chose to immerse ourselves in the particular case of a capital of the country, the one chosen was Rio Grande do Norte, Natal, located in the Northeast region. In this region, responsible for concentrating the largest portion of the PT electorate in the country, three capitals (Natal, João Pessoa and Maceió), in the last elections, channeled the majority of their votes to Jair Bolsonaro.

As a methodological procedure, the article analyzes the voting results of the last 2018 presidential elections in the municipality of Natal, relating them to aspects of the local social reality, in order to map and understand the vote in the light of the political resentment theory (Ferrão 2019; Rodríguez-Pose, 2018). To better present the research findings, we opted for the maps resource, as it allowed a spatial immersion of the political phenomenon in the city's neighborhoods. The selected models were the distribution maps by trend surface, which showed the average distribution of the votes for the candidates Jair Bolsonaro, Fernando Haddad, in addition to the whites/ nulls in the city, allowing to identify the general characteristics of the electorate. The second model was based on the choropleths, which allowed us to analyze the proportion of votes in each neighborhood. The research database is anchored in the Superior Electoral 
Court, and the socioeconomic dimensions were obtained from the repositories of the Municipality of Natal.

For a better illustration, we felt the need to better present the scenario chosen for our research. According to the Brazilian Institute of Geography and Statistics (IBGE, 2019), the municipality of Natal has a population of 884,122 thousand inhabitants, being the twentieth most populous city in the country. Located on the northeastern coast, it has a total area of $169.9 \mathrm{~km}^{2}$, with $100 \%$ of its population located in an urban area.

With regard to social inequality, we can say that the Gini Index went from 0.61 in 1991 to 0.62 in 2010. In recent years, the Municipal Human Development Index (MHDI) in Natal has grown by $15 \%$, from 0.644 in 2000 to 0.763 in 2010 (IBGE, 2010). Natal is characterized, from an economic point of view, by the predominance of the tertiary sector, in which the public service appears as the major employer, being a locality in which the medium sector is predominant.

The following article is structured in three sections. In the first section, we present the reader with brief considerations about the studies developed on the concepts of illiberal democracy and the geography of resentment, which seek to reflect on the profile of new leaders who emerge exponentially in several countries. In the second section, we characterize who are the disgruntled and resentful in Natal, in the light of the Brazilian context, who start to direct their vote and their support to candidates who offer easy solutions to complex problems. Finally, in the third and last section, we make the final considerations in relation to the research inferences.

\section{The geography of resentment and illiberal democracy}

In recent years, traditional parties and leaders have been questioned, as well as the democratic regime itself. Liberal democracy, previously respected and sought after by all, is now being treated in a hostile manner in countries that, until then, have had a trajectory of respect for republican norms and a broad democratic tradition, such as the United States (Mounk, 2018).

The election of figures who publicly oppose constitutional norms that dictated the formation of liberal democracies is an intercontinental reality. These leaders begin to gain more power and influence, as well as greater political representation, and their practices and discourses lead to an illiberal democracy, which is nothing more than a democracy without rights or, better saying, in which liberal constitutionalism comes to be questioned.

It is important to understand that Mounk's idea (ibid.) is based on the view that the population in general - or voters, in a more specific way - considers that the problems present in society can be easily elucidated; these views gain greater prominence when endorsed by populist candidates, since they would not be qualified by the population as a sign of "common sense", but rather as a sign of authenticity of the candidate who presents these propositions.

The difficulty in solving the problems that bother voters daily is seen as a factor of political ill will and the government's inability to respond. The author reinforces 
this argument when he analyzes the American election and the proposals of Donald Trump, who, as an example, proposes to solve the Latin American immigration agenda by building a wall on the border with Mexico. This leads us to the possibility that this proposal can be seen as a sign that the plan presented by the candidate is really the solution to the problems.

\begin{abstract}
Voters do not like to think that the world is complicated. They certainly don't like to know that there is no immediate answer to their problems. Faced with politicians who seem less and less capable of governing an increasingly complex world, many are increasingly willing to vote for those who promise a simple solution. (Ibid., p. 38; our translation)
\end{abstract}

The phenomenon of political resentment is also being studied due to the rise of leaders with an antiliberal character. One way to understand this phenomenon is pointed out from the perspective of "places that matter and places that do not matter". RodríguezPose (2018) is based on the premise that mistaken development strategies adopted in the European continent would have led to a division of several countries into two classifications: those prosperous and dynamic, from an economic point of view, and the other excluded places, placed in second place plan, in which residents, a posteriori, would seek new job opportunities in rising urban centers.

This exclusion, from an economic point of view, would produce a wave of discontent and a reaction that would result in what is called, by Rodríguez-Pose (2018, p. 190), The revenge of the places that don't matter. This term would qualify changes in the perspective of a territorial portion of the electorate that would react against a set of negative factors. These locations are now affected by low rates of economic growth, rising unemployment and poverty, as well as uncertainty about the present and insecurity about any prospect of the future. In this way, these excluded places would start to cast their vote for leaders who have a more populist character and a nationalist profile, linked mainly to the extreme right of the ideological political spectrum. The elections would be a way to bring about this resentment about territorial unrest and, at the same time, a way of expressing resentment in relation to the factors mentioned above.

In the case of Europe, these places would be exemplified mainly by cities that played an industrial role and that noticed, with the advance of globalization, a deterioration in their quality of life and the decay of economic activities previously performed. Resentment would arise not as a personal reaction from all "people who don't matter" - those who consider themselves socially excluded - but rather as a kind of revenge for the territory as a whole, a reaction from places that would also be linked to a nostalgic feeling that the past was more encouraging. Social and interpersonal inequality would be an important factor, but the rise of this leadership profile would start from a territorial inequality that was neglected (ibid., 2018). Still, according to the author,

\footnotetext{
Populism was not established among the poorest, but in a combination of poor regions and areas that have suffered long periods of decline. Therefore, it has been "the places that do not matter" and not "the people that do not matter" that have reacted
} 
In these areas it has very often been the relatively wealthy, those in well-paid or retired jobs that respond to the call of populism (Ibid., p. 201; our translation)

To corroborate the argument, the analysis of the behavior of the electorate in two large urban centers, the city of Paris and New York, demonstrated that, in both, the poorest direct the vote to more systematic candidates and with a discourse more distant from populism. In New York, rich and poor voted together for Democratic candidate Hillary Clinton against Republican Donald Trump. In Paris, this factor would be repeated with the candidacy of Emmanuel Macron, who ran in the second round of the French elections with Marine Le Pen, a far-right candidate. In this way, resentment would not be a reaction from these urban centers, analyzing the case of Europe and the United States (ibid.).

Ferrão (2019), approaching a more specific analysis on the disaffected voters, offers its contribution from a very contributory division that qualifies this phenomenon from the geographical, sociological, economic and cultural aspects. From a geographical point of view, the "disaffected" voters could be qualified as inhabitants of small and mediumsized cities, which had, as Rodríguez-Pose (2018) also pointed out, an industrial past and/ or grounded in rural areas. From a sociological perspective, they would be groups that would be located in the traditional middle and popular classes (workers, public and private sector wages, peasants, self-employed and unemployed), in a situation of social precariousness, with low levels of education and qualification. Economically, they would be populations facing socially vulnerable situations, families with indebtedness and low socioeconomic security. Finally, from a cultural point of view, they would be people who feel that their identity and values are threatened by the urban agenda arising from globalization that directs their focus to cosmopolitan metropolises (Ferrão, 2019).

The effect of globalization on this change in political direction, analyzed in certain territories, may be essentially in the breaking of territorial boundaries that the interaction between global economies resulted in and the consequent change in social and economic habits resulting from this integration. The feeling of exclusion of the discontented voters deepens, and they appear as the "losers of globalization" (ibid., p. 62). Thus, they would start defending deglobalization, policies of a more protectionist and xenophobic nature, based on a new valorization of their moral, religious and cultural identities, very imbued, as recalls Ferrão (ibid.), In the great again, expressions used in the campaign of then American President Donald Trump. Still according to Ferrão (ibid., P. 63):

[...] we are not facing a war between territories, although the geography of the nationalist and xenophobic vote seems to point in that direction. We do face serious problems of spatial injustice and lack of territorial cohesion resulting from the processes of globalization, the power of deterritorialized cosmopolitan networks and the ideal of urban triumphalism.

A question that may flourish is related to what other factors would be used to analyze the crisis of representativeness faced by liberal democracy, which seemed so consecrated on the European and North American continents and which has progressed towards 
consolidation also in Brazil. Ferrão (ibid.) offers this contribution, indicating six trends that he considers transversal. Among them, we could mention here the reduction in electoral participation evidenced by the increase in abstention rates; the electoral retraction and the consequent weakening of center-left and center-right parties; the consolidation of candidates and movements with a nationalist and anti-system character; the low influence of parties with a Marxist bias; the increase in party fragmentation; and low youth interest in direct participation in politics. According to the author:

These six trends related to the practices associated with demoliberal representation systems reflect an increasing distrust and an increasing alienation of citizens in relation to political parties and representative democracy systems (Belchior, 2016), which means that the "representative" function of the elected is less and less effective. (Ibid., p. 58)

In the Brazilian scenario, the trends brought by Ferrão (ibid.) can also be seen in a similar way. The first dimension, the growth of abstentions, even if it was not exponential, is a reality in Brazil. In the 2010 presidential elections, there were 24 million abstentions; in 2014, the number rose to 27 million; and, in 2018 , it rose to 29 million; analyzing only the first electoral round of the three elections. In the second round, the number of abstentions increased from 29 million in 2010 to 30 million in 2014, and in 2018, that number reached 31 million. The data show that, in addition to growth, abstentions obtain higher values in the second rounds of the elections, when compared to the first rounds.
With regard to a second dimension presented by Ferrão (ibid.), In the Brazilian reality, we observe that there is a decrease in the voting of the parties that previously centralized the political debate, mainly those of center-left and center-right politicalideological spectrum. This fact is evidenced when observing, mainly, the data of the Brazilian Social Democracy Party (PSDB) - center-right - which came out of a vote of around $30 \%$, in the 2014 presidential elections, to less than $5 \%$ of the valid votes in the first round of the 2018 presidential elections. The Workers Party (PT), a center-left party, which had $46.91 \%$ of the valid votes in the first round of the presidential elections in 2010 , won just $29.28 \%$ of the votes in the 2018 presidential election. Both parties have polarized presidential elections since 1994. Marxist, Trotskyist or similar parties, on the other hand, never had an expressive vote in Brazilian elections. The biggest vote was in 2014, when candidate Luciana Genro, from the Socialism and Freedom Party (PSOL), reached $1.55 \%$ of the valid votes, which represented just over 1.6 million votes. PSOL is one of the few Trotskyist-oriented parties in the country.

Still analyzing the dimensions proposed by the author, with regard to party fragmentation, we have evidenced, in the Brazilian scenario, based on the 2010 elections, that only 22 parties had representation in the Federal Chamber; in 2014, there were 28 parties; and in 2018, 30 parties achieved electoral representation. The party with the largest bench, the Workers Party, has approximately $11 \%$ of the deputies that make up the Federal Chamber. Thus, the largest electoral fragmentation in history since the country's re-democratization. ${ }^{4}$ 
Regarding the dimension of growth of movements and parties more to the extreme right-wing, in Brazil we also see, aligned with this growth, the rise of figures more linked to conservatism and evangelical churches, such as Marcos Feliciano, Jair Bolsonaro and other leaders who start to appear in the electoral debate. In 2016, a movement more linked to the right side of the political spectrum, the Free Brazil Movement (MBL), strengthens the demonstrations that culminated in the impeachment of ex-president Dilma Rousseff (PT), which demonstrates the serious crisis of representativeness faced by Brazil from 2013.

In the second round, a poll by the Datafolha Institute (Datafolha, 2018) released data about the reasons for voting for Bolsonaro: $30 \%$ of voters said they would vote for him because they wanted a renewal in politics or to elect someone who had never been president; at the same time, $25 \%$ said they voted for the candidate for rejecting the PT, showing a resentment towards the PT in Brazil.

In 2013, several Brazilian cities, mainly the capitals, were the headquarters of large popular demonstrations that initially presented themselves against readjustments in the public transport tariff. With the evolution of demonstrations, the perception is that its character became more diffuse, including guidelines that sought to improve public services and a public management free from corruption, which we can summarize in the idea that the Brazilian citizen claimed actions in favor of democracy (Maricato et al., 2013; Rolnik, 2013; Vainer, 2013; Avritzer, 2016; Almeida et al., 2018). Speaking on the national network, the president at the time, Dilma Rousseff (PT), presented a package of solutions that would be put in place to meet the demand of the protesters who came to carry out large protests in front of the National Congress. Until then, maintaining a high approval from her government, Dilma Rousseff observed her approval drop to the lowest rate since she assumed the presidency in 2011.

Street demonstrations started to take on a supra-partisan character as soon as the presence of party activists or instruments of apology to political parties started to be rejected by protesters in several Brazilian cities, culminating, for example, in the removal of the flags of political parties and leadership. The PT, a party that has always had a history of contact with the most popular classes, since 2014 , is the target of harsh criticism related to corruption in the public sphere of government due to the investigations of Operation LavaJato. This Operation became widely known and disseminated in the national press and, as a consequence, had a polarization in Brazil that created the image of antipetism, which we take as a key element to analyze the resentment of the Brazilian electorate.

\section{Democracy and presidential elections in Brazil and Natal}

Through the 1988 Federal Constitution, Brazilian society once again had the right to choose its own representatives, initiating the resumption of representative democracy in the country, which now has a scenario of the multiparty system structured on an electoral system based on constitutional and republican rules.

In the last decades, representative democracy has passed through a setback when it experiences a moment of crisis, especially 
in the central countries, where this model of democracy has been consolidated. This crisis is revealed both in the participation in the electoral processes, which can be seen from the dramatic increase in abstentionism, and also in the confidence of citizens concerning their representatives.

The dissatisfaction of the people with the functioning of today's democracies highlights the limits of the democracy model that is currently prevalent in capitalist societies, which result in disillusionment with the party politics, distrust of democratic institutions, discontentment with political representatives (given the unprecedented aggravation of the social crisis, the increase in corruption, and the lack of commitment to democratic ideals), as well as the absence, by some citizens, to participate in an election in which the electoral process is seen as the central point of political participation (the act of voting).

The process of the political reopening of Brazilian society, built upon the desire of the population that had gone to the streets to ask for the right to vote for president, denied for 21 years by the military regime, seems to have lost its charm in the face of the last electoral elections. According to the result of the presidential elections from 2010 to 2018, we can see that the abstention rate had small fluctuations, remaining in a proportion above $20 \%$; and the null votes also, in the last three elections, presenting, in the 2018 elections, an increase of $60 \%$.

Graph 1 - Abstention rate, null and white votes, in the Brazilian presidential elections between 2010 and 2018 - 2nd round - Brazil

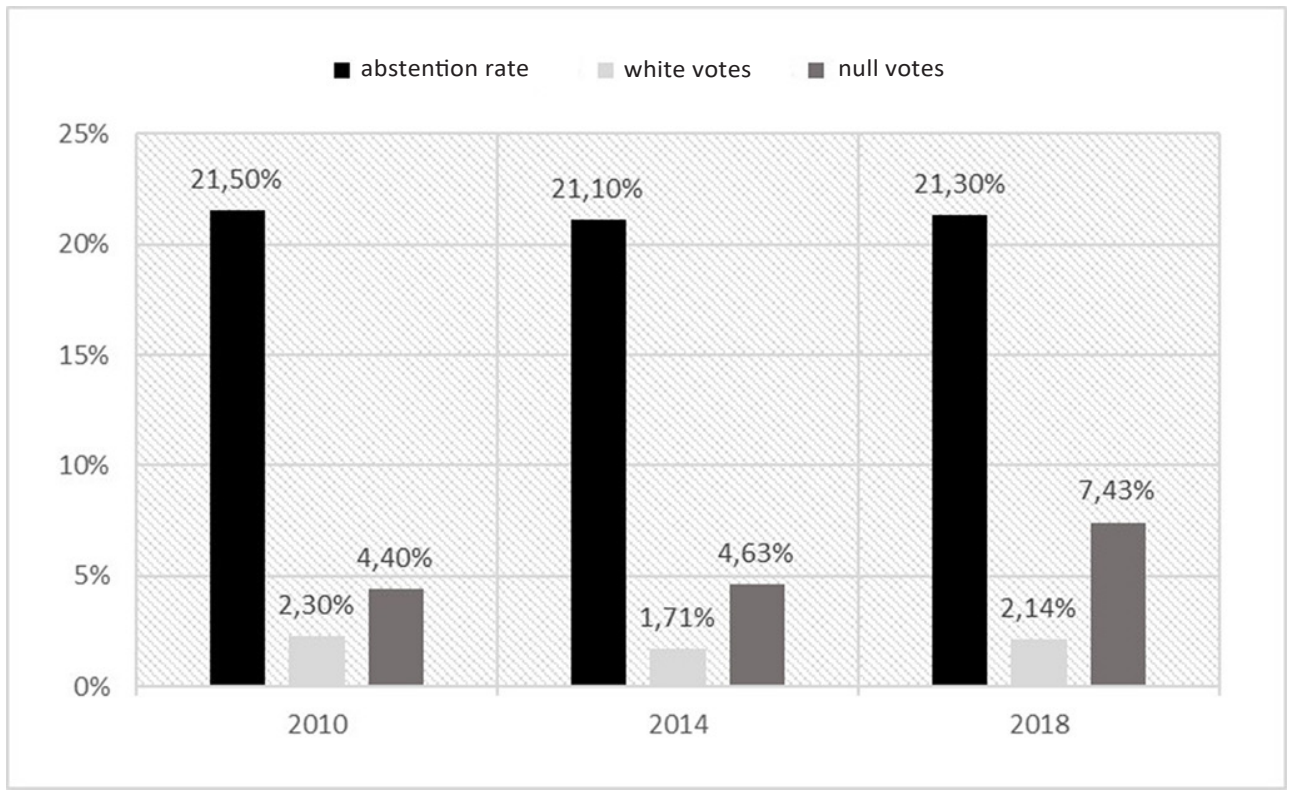

Source: elaborated by the authors, based on TSE data (Brazil, 2020). 
In the context of our study object, the city of Natal, the abstention rate increased by $36.06 \%$ between the 2014 and 2018 elections, jumping from $13.28 \%$ to $18.07 \%$ of the electorate, considering the changes in the number of voters in the same period, while the Brazilian average grew less than $1 \%$ (0.94\%) $)^{5}$ between 2014 and 2018.

Concerning the result of white and null votes, and based on geocoded data, used as a way to better visualize the incidence of votes on localities and their asymmetry in the spatial distribution, it was possible to draw attention to the predominance of white and null votes in territories classified as vulnerable, given the existing social conditions (low level of education and lack of public equipment and services). The districts of Mãe Luiza (21\%),
Felipe Camarão, and Cidade Nova (20\%) had the highest incidence, while the districts of Tirol, Candelária, and Capim Macio concentrated 10\% of the white and null votes. These latter ones have groups with a higher level of education, with greater access to equipment and public services, which may reveal different intentions when choosing between those voting options.

As observed in the map above, there is an expressive number of voters dissatisfied with Brazilian democracy, which can be explained both by the nonattendance of the State in meeting social rights with effective public policies and by the discredit concerning the political actors involved in corruption. Our proposal was not to go deeply into aspects that justify the choice of white and null votes in the socioeconomic or political-institutional sphere.

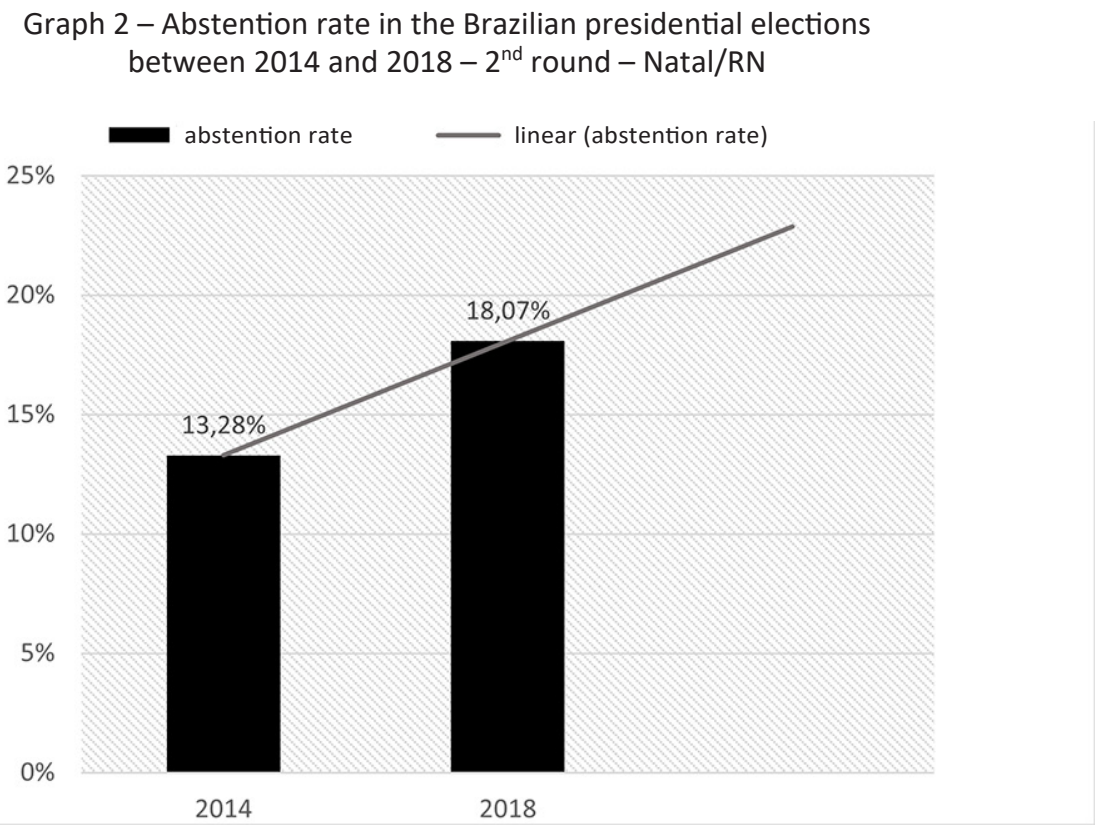

Source: elaborated by the authors, based on TSE data (Brazil, 2020). 
Even because immersing itself in the city's political interest and civic awareness would deserve a more robust analysis. However, the observation presented is an additional element to think that resentment can also come in the option for this type of vote, once, in Brazil, voting is mandatory.
An important aspect to be highlighted in Brazilian politics, which is repeated in the 2018 presidential elections, concerns the old polarization between the PT and the PSDB, parties that have grouped most of the votes since 1994, as analyzed by Limongi and Cortez (2010).

Map 1 - Spatial distribution of votes.

2018 presidential elections, 2nd round - white and null votes

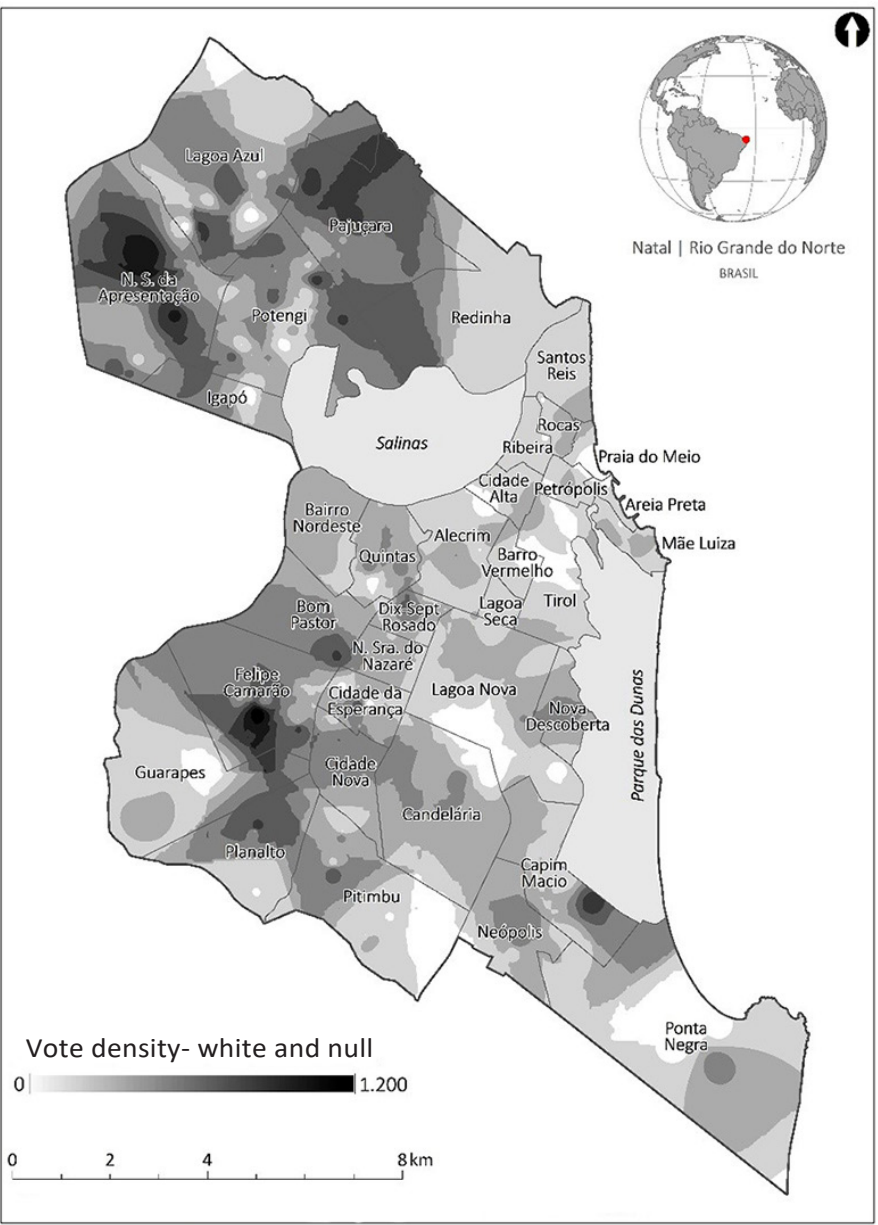

Source: Regional Electoral Court of Rio Grande do Norte (TRE/RN,2018). 
Graph 3 - Result of the Brazilian presidential elections between 1989 and 2014 - Brazil

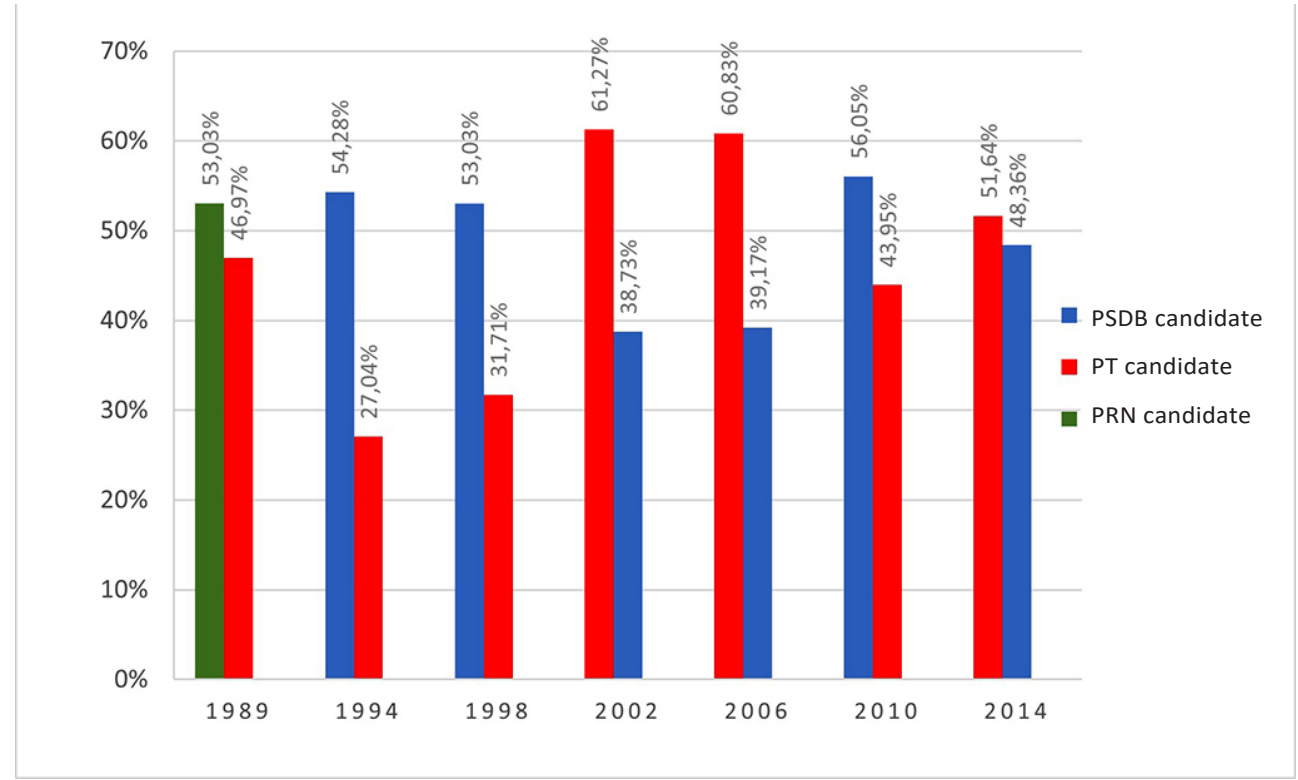

Source: elaborated by the authors, based on TSE data (Brazil, 2020).

Inside the political scenario in Brazil, from 1994 onwards, the PT and PSDB were involved in clashes in all elections. However, in 2018, the PSDB was left out of the second round of the elections, becoming a support player in the main race for the first time in 24 years. Another historic milestone during the 2018 election was the rejection of the candidacy and, subsequently, the arrest of former President Luiz Inácio Lula da Silva (PT), although he was, at that time, among the first places in the election polls.

The 2018 elections are similar to the 1989 ones, having one of the highest numbers of candidates for the presidency in the last 20 years, 13 in total; the main of them were: Jair Bolsonaro (PSL), Fernando Haddad (PT), Ciro Gomes (PDT), Geraldo Alckmin (PSDB) and Marina Silva (Rede).
The candidates most placed at the center of the political spectrum, for example: Geraldo Alckmin (PSDB) and Marina Silva (Rede), who had already run in presidential elections, see their worst results in 2018, as well as the consequent reduction in the voting of their parties. The PSDB had the worst vote rate in history since 1994, and Marina Silva, who had more than 20 million votes in 2014, reached just over 1 million votes in 2018, highlighting the particularity of that election in the country.

The first round boiled down to a dispute between Jair Bolsonaro and Fernando Haddad, who began to centralize the 2018 electoral political debate. Bolsonaro presented himself as an anti-system candidate and, at the same time, antipetista, who channeled his performance in the rejection of the PT governments, which ruled the country for 13 
consecutive years. Therefore, Jair Bolsonaro raised the anti-corruption, anti-system flag, placing himself as a staunch defender of a liberal-conservative agenda that emerged victorious in the elections.

The main opponent of the current president of Brazil, professor Fernando Haddad (PT), former mayor of São Paulo and former minister of education during Lula and Dilma governments, tried to attract the electorate that benefited from the social and economic policies of the Workers' Party governments, trying to govern, at the last minute, the votes of former President Lula for his candidacy. However, regarding the electoral results obtained by the candidate, it is worth pointing out that they were the worst for a Workers' Party candidate since 2003 when the party reached the Presidency of the Republic.

With a high strength in the social networks, the political polarization, already evidenced previously, gains a new dimension, insofar as a party without great numerical expression enters the scene in the Chamber of Deputies, which had a reduced TV time, directing the entire presidential campaign of Bolsonaro for digital media. The thencandidate managed to increase his popularity, gaining greater media attention, after being attacked by an attempt on his life, in the middle of the electoral race, which caused his absence in the electoral debates broadcast by several TV stations during the presidential campaign, as well as the consequent increase in voter intentions. According to a survey by Ibope ${ }^{6}$ carried out in September 2018, Bolsonaro grew by 4 percentage points after the attack, from $22 \%$ to $26 \%$ of voting intentions.
Another important aspect to highlight was the appeal to the conservatism of the electorate in favor of the candidacy of Jair Bolsonaro, which stood as a symbol candidate of a new way of doing politics, forgetting his public career of 28 years as a parliamentary deputy for five terms, always acting in Congress in what is known in Brazil as "lower clergy". His anti-system candidacy classified him as "a new leadership" in Brazil that, despite the lack of political expression and the absence of a large party coalition that would help him to come to power, did not prevent him from winning in the second round of the elections, winning 55.13\% of the valid votes, against $44.87 \%$ of the runnerup, winning in 16 states and 21 capitals. In the Northeast, a primarily PT stronghold, he won victories in the capitals of Rio Grande do Norte, Alagoas, and Paraíba.

The scenario of the elections in the municipality of Natal, the twentieth most populous city in the country, has a history of political rivalry between traditional families, which both enabled the emergence of new leaders and the maintenance of old ones. However, as of the 1990s, the city began to have a leadership of the PT in the dispute for the municipal executive, initiating a political trajectory in the state of Rio Grande do Norte. ${ }^{7}$ Regarding the holding of elections in the capital, it is important to highlight that Natal has five electoral zones and a total of 557,715 voters able to vote (Brazil, 2020). Considering the period from 1989 to 2014, in the capital of Rio Grande do Norte, the Workers' Party was victorious in four electoral disputes (1989, 2002, 2006 and 2014), demonstrating the strong influence of the Federal Government in the local context. 
Graph 4 - Result of the Brazilian presidential elections between 1989 and 2014 - Natal/RN

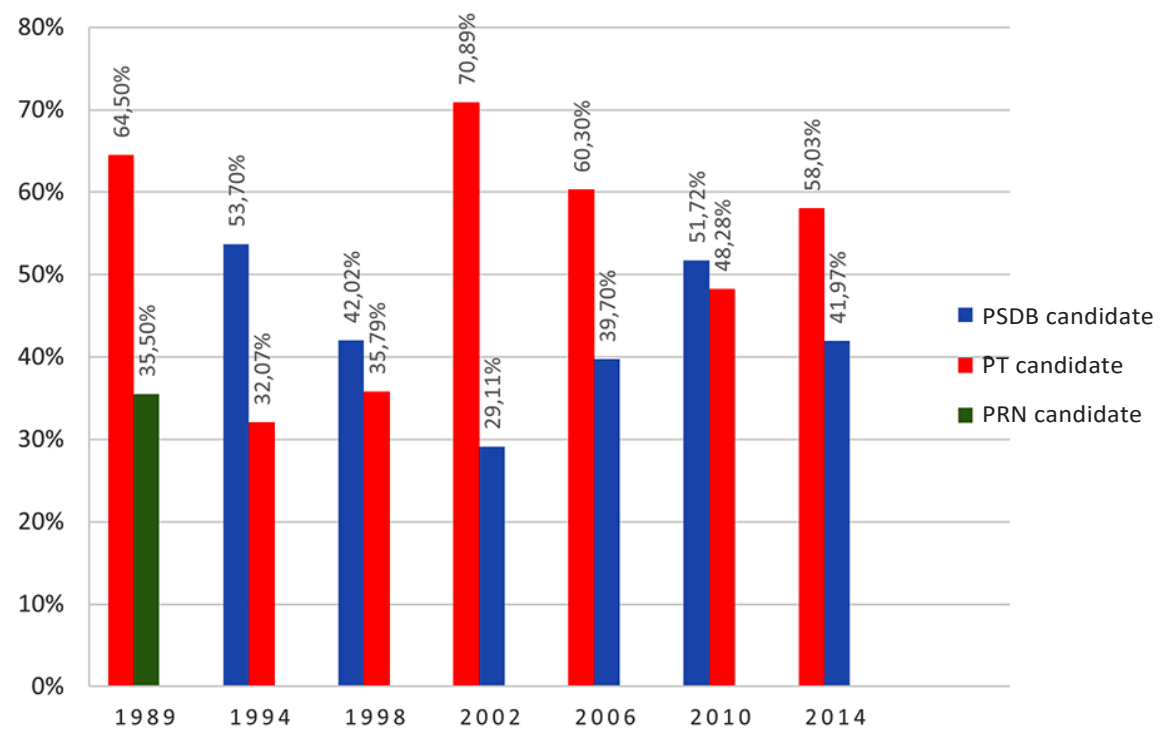

Source: elaborated by the authors, based on TSE data (Brazil, 2020).

For an understanding of the 2018 elections in Natal, we initially chose to analyze the 35 neighborhoods based on the voting of the presidential candidates and the quantity of white/invalid votes obtained in the second round of elections, which was possible from the selection of the variables obtained from the databases of the Superior Electoral Court (TSE), presented in Table 1. The table presents the vote of each candidate through statistical measures of average and median, as well as the minimum and maximum vote that candidates received in the city's neighborhoods. Thus, it can be observed that the average vote of candidate Jair Bolsonaro in Natal was 6,434 votes, with the minimum vote obtained in a neighborhood of 602 votes and the maximum vote of 27,371 votes. The candidate Fernando Haddad had an average of 5,688 votes, with the minimum vote obtained in a neighborhood of 638 votes and the maximum vote of 24,065 votes. 
Table 1 - Description of the political dimension variables for Natal/RN, 2018

\begin{tabular}{|l|c|c|c|c|c|}
\hline \multicolumn{1}{|c|}{ Variable } & Average & Median & Standard deviation & Minimum & Maximum \\
\hline Fernando Haddad (PT) votes & $5.688,31$ & $3.822,00$ & $4.923,99$ & 638 & 24.065 \\
\hline Jair Bolsonaro (PSL) votes & $6.434,26$ & $4.429,00$ & $5.812,28$ & 602 & 2.7371 \\
\hline Null and white votes & $2.260,6$ & 1.604 & $2.118,581$ & 203 & 10.520 \\
\hline
\end{tabular}

Source: elaborated by the authors based on an authorial research database, in 2020.

In the 2018 election dispute, we can draw attention, from the data obtained, to the fact that the electorate of Natal opted for presidential candidate Jair Bolsonaro since the first round, whose results for the top four were: Jair Bolsonaro (PSL) 44,42\%; Ciro Gomes 23,57\% (PDT); Fernando Haddad (PT) 22,8\%; and Geraldo Alckmin (PSDB) 2,76\%.

In the dispute of the second round, Jair Bolsonaro had $52.98 \%$ and Fernando Haddad $47.02 \%$ of the total valid votes. As we can see, on the map below, the polling places identified as high concentration of votes have a higher occurrence for candidate Fernando Haddad in the sections existing in the 4th electoral zone of the city, while his opponent managed to win in the other zones (1st, 2nd, 3rd and 69th). In this way, it is possible to notice the results divided by electoral zones: 1st zone: Bolsonaro 51.27\% x Haddad 48.73\%; 2nd zone: Bolsonaro $55.59 \%$ x Haddad 44.41\%; 3rd zone: Bolsonaro $56.79 \%$ x Haddad 43.21; 4th zone: Haddad $50.51 \%$ x Bolsonaro 49.49\%; and 69th zone: Bolsonaro $50.55 \%$ x Haddad $49.55 \%$.
It is possible to notice based on the variables expressed in the map of distribution by trend surface which were the results of candidates Fernando Haddad and Jair Bolsonaro in the city. Considering that Natal had $23.5 \%$ of the electorate of Rio Grande do Norte, ${ }^{8}$ the map provides an approximate view of the spatial distribution of votes. The geocoded data were separated by competitors as a way to better visualize the incidence of votes on the localities and their asymmetry in the spatial distribution. The trend surface maps show the average distribution of the votes of candidates Jair Bolsonaro and Fernando Haddad, and its reading allows to identify the general characteristics of the electorate in Natal, mainly the plots of the territory in which there is greater electoral density.

In the Northern Administrative Region, we observed a difference, especially in the Pajuçara neighborhood, where the choice for Haddad tends to be stronger. In the Southern Administrative Region, especially in the neighborhood of Capim Macio, the choice 
tends to be stronger due to the candidacy of Bolsonaro. In addition, it is possible to point out a slight predominance of Bolsonaro in the most central area of Natal - Tirol, Cidade Alta and Petrópolis neighborhoods - although the maps show a strong balance in the dispute Fernando Haddad versus Jair Bolsonaro throughout the city.

Map 2 - Spatial distribution of votes.

Elections 2018, 2nd round - Fernando Haddad (PT)

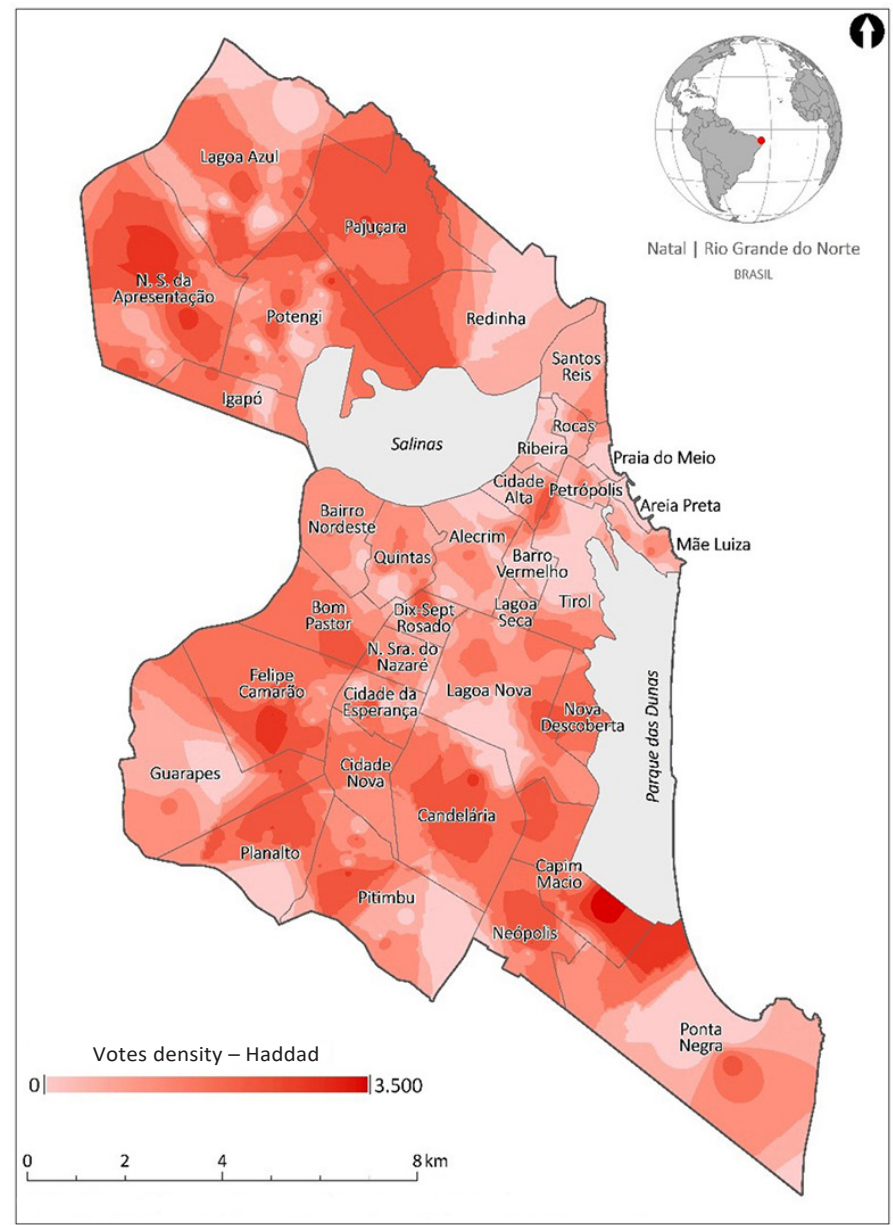

Source: Regional Electoral Court of Rio Grande do Norte (TRE/RN,2018) 
Map 3 - Spatial distribution of votes.

Elections 2018, 2nd round - Jair Bolsonaro (PSL)

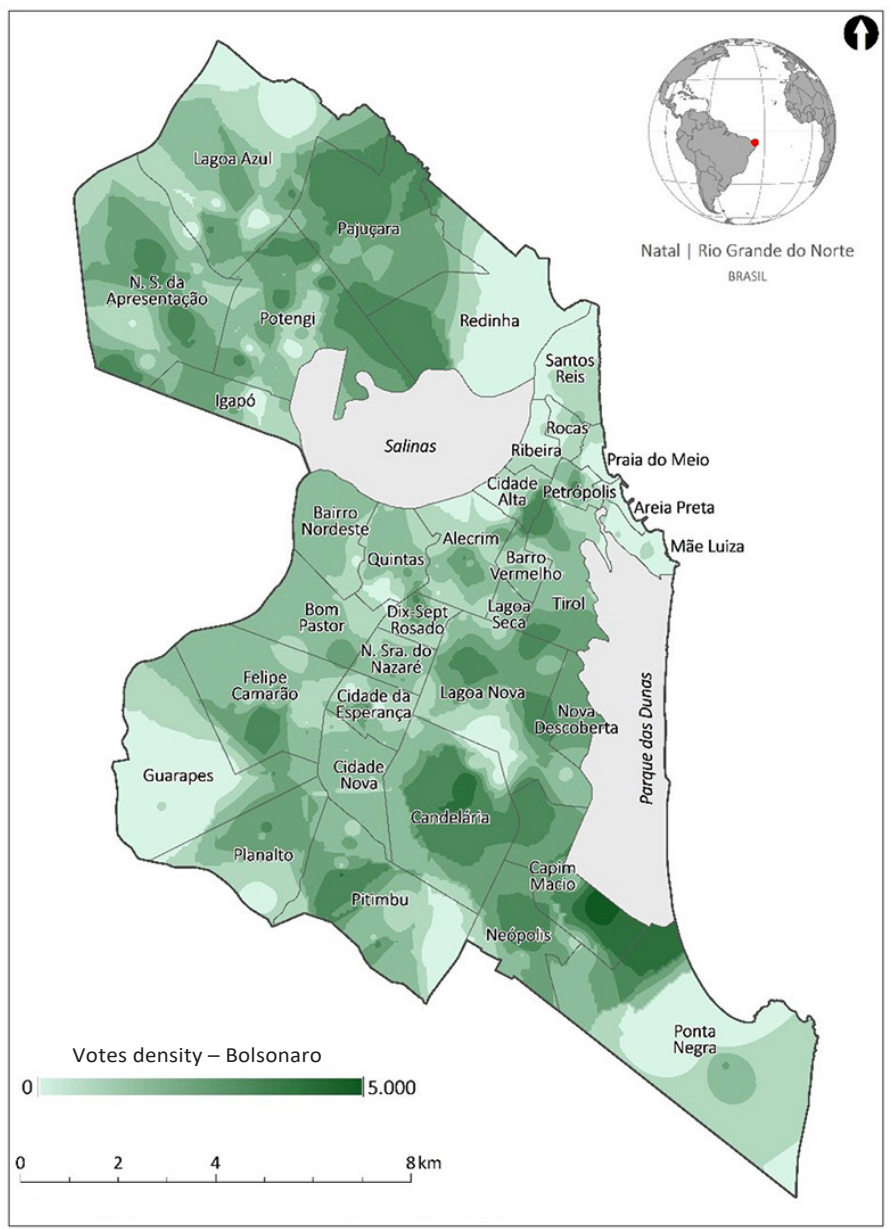

Source: Regional Electoral Court of Rio Grande do Norte (TRE/RN,2018).

Comparing the previous Fernando Haddad's and Jair Bolsonaro vote maps, we could check that the voter of Natal decided for the victory of the current president in most neighborhoods. However, it is important to point out that there was a fierce dispute in all polling stations, varying from a majority of $1 \%$ to $5 \%$ more than the second place. Thus, we found a strong correlation between the degree of competitiveness of voting in each area of the city and the distribution of socioeconomic characteristics of the municipality's population. 
In all areas of the city, the vote is balanced between the two candidates, regardless of the area in which the ruling elites or the most socially peripheral sectors are located. A slightly higher concentration of the petitioner votes predominated in the 4th electoral zone, where Guarapes, a peripheral neighborhood of Natal, is located. This location is characterized by the predominance of a low-income population that is in need of services and has high rates of urban violence. The only location where Fernando Haddad received more than $50 \%$ of the vote was in the neighborhood mentioned above. The city hall data regarding the neighborhoods of the city show that the neighborhood aforementioned

Map 4 - Spatial proportion of votes by neighborhood.

Elections 2018, 2nd round - Fernando Haddad (PT)

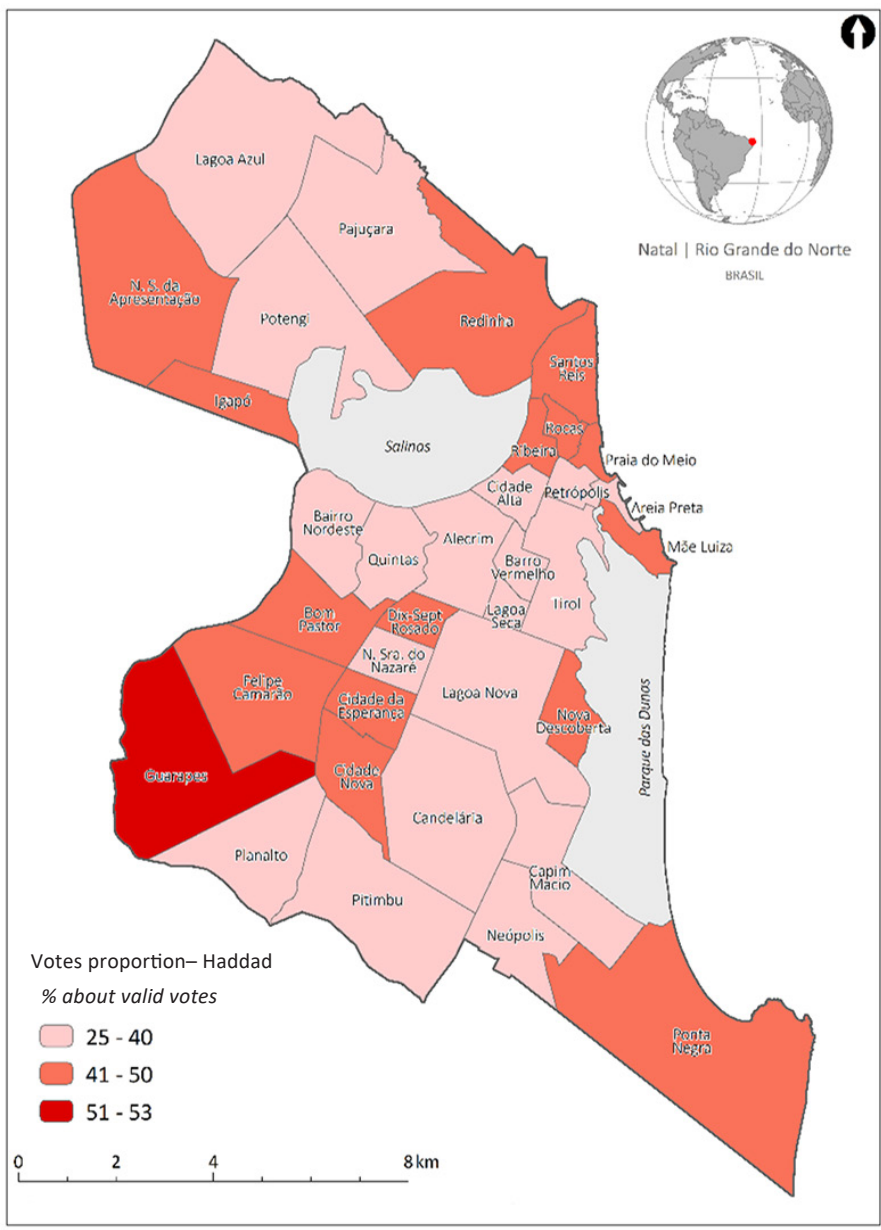

Source: Regional Electoral Court of Rio Grande do Norte (TRE/RN,2018). 
has an average monthly nominal income of 0.53 , below the city average, which is 1.78 minimum wages. Regarding literacy rates, Guarapes has, for the literacy of people aged 5 years or more, a percentage of $72 \%$. In addition, $33.47 \%$ of its population is exposed to open sewage (Natal, 2016).
The Workers' Party also obtained a significant vote in Mãe Luiza (49\%), Redinha and Santos Reis (47\%) and Ponta Negra (45\%). With the exception of Ponta Negra, all other neighborhoods also have peripheral characteristics, and it is possible to find a strong correlation of these results with

Map 5 - Spatial proportion of votes by neighborhood.

Elections 2018, 2nd round - Jair Bolsonaro (PSL)

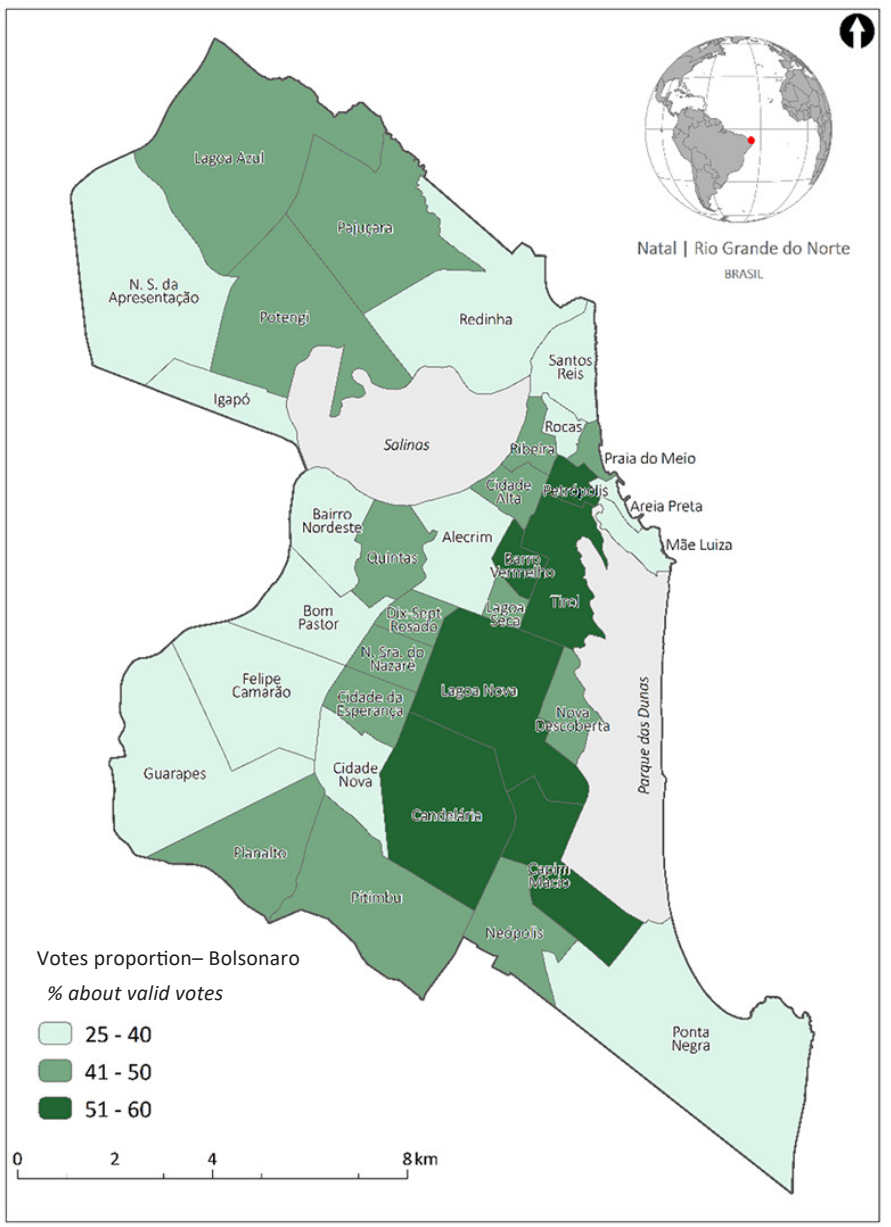

Source: Regional Electoral Court of Rio Grande do Norte (TRE/RN,2018). 
socioeconomic characteristics. In addition, it is important to highlight the influence of social programs of the PT government, as the Bolsa Família Program (PBF), the candidate vote Haddad.

Regarding the vote of candidate Jair Bolsonaro, we observed that he emerged victorious in 4 of the 5 electoral zones, losing only in the 4th electoral zone, as previously mentioned. There is a concentration of their votes, mainly in the upscale neighborhoods of the city, such as: Tirol (60\%), Barro Vermelho (57\%), Candelária (54\%), Lagoa Nova (52\%), Capim Macio (51\%), Areia Preta (51\%) and Petrópolis (51\%). These neighborhoods have a monthly nominal income average ranging from 6.74 (Tirol) to 4.01 (Lagoa Nova) and all of them have a literacy rate above $96 \%$ (ibid.). These results reveal that the dissatisfaction with PT governments is also located in neighborhoods in the city that have a population with a higher level of education, with higher per capita incomes in the city, and with a greater supply of public equipment and services.

This research was not concerned with becoming an accumulation of descriptions of phenomena. The attempt was to go beyond the immediate data, mainly for something that was not directly observed, and, through the use of maps, to support a spatial immersion of the political phenomenon by the city's neighborhoods. Given this context, it is necessary to draw attention to the fact that the resentful voter is not located only in excluded places. The resentment arose not only as a personal reaction from all "people who don't matter", but also from those who are socially included. We can see that the vote is not concentrated only in contexts that have experienced an economic and social decline in the city, the result of an impoverishment caused by the economic recession that has afflicted the country in recent years. But, it seems, that the resentment contemplates different social groups who feel mobilized by ethical values and principles of the public sector that were threatened by the political dynamics of the country.

A feeling of hatred against the PT's legacy developed, even more radically, the aforementioned polarization, initiating the creation of a political phenomenon called Jair Bolsonaro, "the myth". Therefore, the analysis of the behavior of the Natalense electorate demonstrated that the resenting electorate is distributed in several locations, not only in peripheral regions, contemplating different socioeconomic profiles.

\section{Final remarks}

As the conclusions for political phenomena today are relatively uncertain, essentially because this universe has been changing rapidly in recent years, the analyzes undertaken here help to understand them, even when the inaccuracies about our conclusions are high. The intention was to contribute to the construction of scientific explanations for the understanding of the "resentful voter" (Ferrão, 2019) in the Brazilian context, given the prominence that this theme has been gaining in several countries in the world. The choice for the last elections happens, precisely because it is in them that this phenomenon gains dimensions that have been affecting the way of doing politics in Brazil. 
We found, from the analysis developed here, that the reduction in electoral participation evidenced by the increase in abstention rates and the high percentage of white and null votes, as well as the weakening of traditional parties of Brazilian centerleft (PT) politics and center-right (PSDB), fortified a candidacy with a nationalist and anti-system discourse, further accentuating the polarization between the left and the right in Brazil, both through the politicalparty discourse and for the production of an image of a government marked by ideals that characterize it from the perspective of illiberal democracy, structured in a movement of opposition to the progressive mainstream.

In addition to this understanding, the voters' perception of traditional candidates has eroded from the moment when everyday problems did not seem to have effective solutions. Jair Bolsonaro emerges as a candidate who presented simplistic solutions to solve them, giving new hope, or even an illusion, to those who were not optimistic about the future. We observe here the idea of "your voice is me" (Mounk, 2018), imbued in the behavior of the candidate who presented himself as a figure totally averse and distant from the traditional political class, but close to the popular desire for change - qualifying himself as a representative morality of that desire. Using the motto "Brazil above everything, God above everyone", the candidate sold his conservative agenda, linked to international interests, in which Brazilians would be in the first place. "American first", Donald Trump said similarly. Therefore, as a "seller of illusions", Bolsonaro consecrates his victory in a country that coped with a scenario of pessimism in the face of the economic crisis and, above all, politics that devastated the nation, given the cases of corruption involving political actors who led Brazil.

We will probably have an opportunity, in future research, to rediscover new explanations about the resentment channeled towards white and null votes in the city of Natal. In the analysis carried out here, under the elucidation of the authors approached here, we found a significant increase in white and null votes, which can be justified by the dissatisfaction of the electorate with the candidates presented in the 2018 election. A path not followed by the authors, since, in Brazil, voting is mandatory.

At the end of this study, we have the notion that our contribution could be much greater on the history of the 2018 elections in Brazil than necessarily attesting to all the hypotheses already found in the European scenario. Especially because the resentment had no specific class, place, or economic group as verified in Natal. The country's recent political consequences seem to affect everyone, being the main element in the current government's discourse.

Therefore, we conclude that, for the existence of a consolidated democracy in Brazil, regardless of the candidates and their political and party ideologies, we need to demand competent representatives and responsive state institutions, guided by democratic governance capable of ensuring social, political, and civil rights that were so costly to Brazilian society. 


\section{[I] https://orcid.org/0000-0002-8520-3530}

Universidade Federal do Rio Grande do Norte, Centro de Ciências Humanas, Letras e Artes, Departamento de Políticas Públicas. Natal, RN/Brasil.

almeida.lindijane@gmail.com

\section{[II] https://orcid.org/0000-0002-1829-9413}

Universidade do Estado do Rio Grande do Norte, Faculdade de Filosofia e Ciências Sociais, Departamento de Ciências Sociais e Política. Mossoró, RN/Brasil.

terezinhaalbuquerque@yahoo.com.br

\section{[III] https://orcid.org/0000-0002-7239-5932}

Universidade Federal do Rio Grande do Norte, Centro de Ciências Humanas, Letras e Artes, Programa de Pós-Graduação em Estudos Urbanos e Regionais. Natal, RN/Brasil.

jaylanfmacedo@gmail.com

Translation: this article was translated from Portuguese to English by Spell Jr Assessoria em Língua Inglesa - spelljrassessoria@gmail.com

\section{Notes}

(1) Antipetismo is a term used to designate a feeling of aversion to the ideology or practices of the workers' party.

(2) Operation Lava-Jato was triggered by the Federal Public Ministry (MPF) in 2014 in order to investigate public resource deviations, initially from state-owned Petrobras, for actors and political parties. The investigations reached figures from various parties, including former President Lula (PT) and former senator, and current federal deputy, Aécio Neves (PSDB). The investigations initiated at the federal level also came to be instituted in the states of the federation, resulting in the arrest of former governors and former deputies, can be cited, among them, the former minister of government Dilma and candidate for governor of Rio Grande do Norte, in 2014, Henrique Alves (MDB).

(3) The President Jair Bolsonaro, at the time of drafting the article, is without a party.

(4) Data collected on the Chamber of Deputies website. Available in: https://www.camara.leg.br/ deputados/bancada-na-posse. Accessed on: August 3, 2020.

(5) The data on fluctuation in abstention rates were calculated by the authors based on the data collected on the Superior Electoral Court (TSE) website.

(6) Ibope Survey data released by Gazeta do Povo newspaper. Available in: https://www. gazetadopovo.com.br/politica/republica/eleicoes-2018/efeito-facada-bolsonaro-sobe-noibope-e-melhora-ate-desempenho-no-2-turno-7c47y6qwjoaefjjj98b34vgge/. Accessed on: August 2, 2020. 
(7) Fátima Bezerra emerges as the main PT leadership in the city. She was a federal deputy (20032015), senator (2015-2018) and elected governor of Rio Grande do Norte in 2018.

(8) Data calculated by the authors based on the statistics of the Regional Electoral Court of RN (TRE/RN).

\section{References}

ALMEIDA, L. et al. (2018). Os movimentos sociais urbanos em Natal/RN: uma análise sobre a Primavera de junho na Cidade do Sol. Revista de Geografia e Ordenamento do Território, n. 13. Centro de Estudos de Geografia e Ordenamento do Território, pp. 7-32, dx.doi.org/10.17127/ got/2018.13.001.

AVRITZER, L. (2016). Impasses da democracia no Brasil. Rio de Janeiro, Civilização Brasileira.

BRASIL (2019). Bancada na posse. Câmara dos Deputados. Disponível em: https://www.camara.leg.br/ deputados/bancada-na-posse. Data de acesso: 3 ago 2020.

(2020). Repositório de Dados Eleitorais do TSE. Disponível em: http://www.tse.jus.br/eleicoes/ estatisticas/repositorio-de-dados-eleitorais-1/repositorio-de-dados-eleitorais. Data de acesso: 8 ago 2020.

CASTELLS, M. (2018). Ruptura: a crise da democracia liberal. Rio de Janeiro, Zahar.

DAHL, R. (1996). “A Democracia Poliárquica”. In: DAHL, R. Prefácio à teoria democrática. Rio de Janeiro, Zahar.

DATAFOLHA (2018). Desejo de mudança e rejeição ao PT alavancam candidatura de Bolsonaro. Disponível em: http://datafolha.folha.uol.com.br/eleicoes/2018/10/1983550-desejo-demudanca-e-rejeicao-ao-pt-alavancam-candidatura-de-bolsonaro.shtml. Acesso em: 28 jul 2020.

FERNANDES, A. S. A.; TEIXEIRA, M. A. C.; DA SILVA PALMEIRA, J. (2020). A longa conjuntura crítica brasileira desde 2013: crise e castigo. Cadernos Gestão Pública e Cidadania, v. 25, n. 81.

FERRÃO, J. (2019). "Para uma geografia com todos os lugares: reflexões a partir do caso europeu". In: FERREIRA, A.; RUA, J.; MATTOS, R. C. de. Produção do espaço: emancipação social, o comum e a "verdadeira democracia. Rio de Janeiro, Consequência.

IBGE (2010). Censo 2010. Disponível em: https://censo2010.ibge.gov.br/. Acesso em: 7 jul 2020.

(2019). Natal. Disponível em: https://cidades.ibge.gov.br/brasil/rn/natal/panorama. Acesso em: 7 jul 2020.

IBOPE (2018). Notícias e Pesquisas. Disponível em: https://www.ibopeinteligencia.com/noticias-epesquisas/?tema=13\&ano=2018. Acesso em: 28 jul 2020.

KAPLAN, R. D. (2009). The revenge of geography. Foreign Policy, n. 172, pp. 96-105.

LIMONGI, F.; CORTEZ, R. (2010). As eleições de 2010 e o quadro partidário. Novos estudos CEBRAP, n. 88, pp. 21-37. Disponível em: https://www.scielo.br/scielo.php?pid=S010133002010000300002\&script=sci_arttext. Acesso de: 8 jul 2020.

MAINWARING, S.; BRINKS, D.; PÉREZ-LIÑÁN, A. (2001). Classificando Regimes Políticos na América Latina. Dados, v. 44, n. 4, pp. 645-687. 
MARICATO, E. et al. (2013). Cidades Rebeldes: Passe livre e as manifestações que tomaram as ruas do Brasil. São Paulo, Boitempo e Carta Maior.

MOUNK, Y. (2018). The people vs. democracy: why our freedom is in danger and how to save it. Cambridge, Harvard University Press.

MOVIMENTO PASSE LIVRE (2013). "Não começou em Salvador, não vai terminar em São Paulo". In: MARICATO, E. et al. Cidades Rebeldes: Passe livre e as manifestações que tomaram as ruas do Brasil. São Paulo, Boitempo e Carta Maior.

NATAL (2016). Anuário de Natal 2016. Disponível em: https://www.natal.rn.gov.br/bvn/publicacoes/ anuario_2016.pdf. Acesso em: 18 jul 2020.

(2017). Conheça Melhor seu Bairro (Região Administrativa Sul). Disponível em: https://natal. rn.gov.br/semurb/planodiretor/anexos/estudos/CONHE\%C3\%87A\%20MELHOR\%20SEU\%20 BAIRRO\%20-\%20ZONA\%20SUL.pdf. Acesso em: 18 jul 2020.

(2017). Conheça Melhor seu Bairro (Região Administrativa Leste). Disponível em:https://natal. rn.gov.br/semurb/planodiretor/anexos/estudos/CONHE\%C3\%87A\%20MELHOR\%20SEU\%20 BAIRRO\%20-\%20ZONA\%20LESTE.pdf. Acesso em: 18 jul 2020.

(2017). Conheça Melhor seu Bairro (Região Administrativa Norte). Disponível em:https://natal. rn.gov.br/semurb/planodiretor/anexos/estudos/CONHE\%C3\%87A\%20MELHOR\%20SEU\%20 BAIRRO\%20-\%20ZONA\%20NORTE.pdf. Acesso em: 19 jul 2020.

(2017). Conheça Melhor seu Bairro (Região Administrativa Oeste). Disponível em:https://natal. rn.gov.br/semurb/planodiretor/anexos/estudos/CONHE\%C3\%87A\%2OMELHOR\%20SEU\%20 BAIRRO\%20-\%20ZONA\%20OESTE.pdf. Acesso em: 19 jul 2020.

PRZEWORSKI, A. (1999). Minimalist conception of democracy: a defense. Democracy's value, v. 23, pp. 12-17.

RODRÍGUEZ-POSE, A. (2018). The revenge of the places that don't matter (and what to do about it). Cambridge journal of regions, economy and society, v. 11, n. 1, pp. 189-209.

ROLNIK, R. (2013). “As vozes das ruas: as revoltas de junho e suas interpretações”. In: MARICATO, E. et al. Cidades rebeldes: Passe Livre e as manifestações que tomaram as ruas do Brasil. São Paulo, Boitempo e Carta Maior.

SILVA, A. dos S.; CARVALHO NETO, A. (2012). Uma contribuição ao estudo da liderança sob a ótica weberiana de dominação carismática. RAM. Revista de Administração Mackenzie, v. 13, n. 6, p. 20-47.

SCHUMPETER, J. A. (1942). Capitalism, socialism and democracy. Nova York, Harper \& Row.

VAINER, C. (2013). “Quando a cidade vai às ruas”. In: MARICATO, E. et al. Cidades rebeldes: Passe Livre e as manifestações que tomaram as ruas do Brasil. São Paulo, Boitempo e Carta Maior.

WEFFORT, F. C. (2003). O populismo na política brasileira. Rio de Janeiro, Paz e Terra.

ZAKARIA, F. (1997). The rise of illiberal democracy. Foreign Affairs, v. 76, pp. 21-22. 